\title{
Hujjat Allah Al-Balighah: The Uniqueness of Shah Wali Allah Al-Dihlawi's Work
}

Fadlan Mohd Othman ${ }^{1}$

Lutpi Mustafa ${ }^{1}$

Mohd Arif Nazri1

Ahamad Asmadi Sakat ${ }^{1}$

Abur Hamdi Usman²

Mohd Akil Muhamed Ali 1

Muhamad Rozaimi Ramle ${ }^{3}$

\author{
${ }^{1}$ Faculty of Islamic Studies, The National University of Malaysia, Malaysia \\ 2 International Islamic University College Selangor (KUIS), Malaysia; Corresponding Author Email: aburhamdi@kuis.edu.my \\ ${ }^{3}$ Faculty of Human Sciences, Sultan Idris Education University, Malaysia
}

Doi:10.5901/mjss.2015.v6n5s1p403

\section{Abstract}

This study reviews on the uniqueness of the book Hujjat Allah al-Baligha by al-Dihlawi that emphasizes two important aspects, in terms of thought and debate on the topics presented by him. The study found al-Dihlawi's thoughts in this book reflect his idealism as an Islamic scholar. He expressed impressive thoughts with the Qur'an as a fundamental ingredient and Sunna as a commentator to the Qur'an. While the reflection may generate useful perspective from the point of significance or preference according to the prevailing realities. Due to dissension between the Islamic parties during that time was considered chronically. This anxiety inspired a number of ideas to him to rebuild civilization of life in the name of Islam without mingling with the seeds of superstition and believing in mythical.

Keywords: Hujjat Allah al-Balighah, al-Dihlawi, Sufism, Juriprudence

\section{Preliminary}

Shah Wali Allah al-Dihlawi (d. 1762) is not only an extremely impressive thinker, but also, when he is not being Indian, a thoroughly Islamic one. Other leading thinkers of the Muslim world have tended either to stand within the Greek philosophical tradition or at least to keep very close to it. But al-Dihlawi has a resolutely anti-philosophical position, frimly inside the religious sciences of Islam. He has been the subject of many modern studies (Baldick, 1992). Here this study looks at his thought as contained in the admirable work Hujjah Allah al-Balighah (The Concuive Argument from God).

This book is one of the prominent work among the scholars due to its contents was applied the aspects of mysticism which is combined with jurisprudence as well. The pattern of its deliberations are similar to Ihya Ulum al-Din (Revival of Religious Sciences) by al-Ghazali (d. 1111), which emphasizes the secret of Islamic law and philosophical constitution elements. Al-Dihlawi had quoted the view of al-Ghazali when commenting on the punishment of the grave issues (Al-Dihlawi, 2005).

His most famous work, Hujah Allah al-Balighah, a short of philosophy of religion was taught at al-Azhar University in Cairo for a considerable period of time (Rahman, 2003). In addition, this book has also been issued in Egypt in various editions and translated into many languages, such as French (Siddiqi, 1966), English by Hermansen (2005), Urdu by Maulana Abu al-Haq Haqqaniy (1978), Maulana Sa'eed Ahmad Palanpoori (2004) and Sheikh Ubayd Allah Sindhi (2010). While in Malay, the book is translated by Zainuddin Hj. Idris and Nik Hassan Nik Abdullah (2002). In Indonesian, the book has been translated by Nuruddin Hidayat and C. Ramli Bihar Anwar (2005).

Al-Dihlawi attempts to elucidate the deeper levels of meaning of traditional symbols and practices while integrating mystical, intellectual, and traditional textual approaches to their interpretation. He understood his mission to be the integration of the increasingly fragmented and disparate articulations of the Islamic intellectual tradition in his own lifetime 
and thus he sought for a mode of expression which would simultaneously draw on the tools of demonstrative proof of the philosophers ant the theologians, sufi mystical insight into the higher realities of things, and the authority of the words of the transmitted textual sources of the Qur'an and the hadith (Hermansen, 2005).

Al-Dihlawi in this book spells out his conception of the relationship between theology and sovereignty, balancing the absolute powers of the ruler with demands of social justice and an equitable political order. Described as 'theological sociology' the hujjat Allah al-Baligha is a syntethic work of history, philosophy, law, theology, as well as a psychological analysis of human nature. He interpreted sacred law (shari'a) as a body of injuction in accordance with man's instinctive intuitions. On this view, prophetic reform was the revival of the potentialities inherent in human societies (Kaplan, 2010).

\section{Paradigm of Discourse towards Purification of Mind}

Al-Dihlawi tried to apply his ideas practically by directing to the society in order to urge them to the bosom of Allah and the Sunnah of the Prophet, as they drifted in the flow of heresies, superstitions and has become deviated by mysticism. It means his thoughts were so full of reform pattern for repairing the system of servitude that emphasizes the authentic faith control of the divinity of God, a spiritual system that will shaping the moral values and civilization, the global economic system that generates social life through the proper channels and transactions system that connects the tolerance of our fellow human beings. His thought covering various aspects of which cross the secular and religious debate with a combination of spiritual and physical elements as the foundation. This setting shows that he was an active thinker and constantly flushed his ideas as a step towards the innovation, renewal and development of a prosperous nation.

The topics in this book stressed on the interest or priorities according to occur realities. He saw the fiasco which takes place between conflicting groups was in the chronic phase, such as the traditionalists and rationalists, jurists and mystics. This case puts Muslims in a wobbling state in the middle of crossroads. These concerns thus have sparked more ideas to al-Dihlawi to rebuild civilization in the name of Islam itself without mingled with the seeds of superstition and irrational. He began this book by examining asbab al-takhlif wa al-majazah (the reasons for deviation and penalty) aspects, which argue regarding the issue of the relationship with the divine and the human, muslims belief concerning the obligation to obey the law, spiritual and physical points, legal issues and including the recompense after death. His comments largely deal with the bonding affinity with the divinity of God and human dependence tightly to the Islamic laws (Al-Dihlawi, 2005).

Focusing on the stability of a country perspective, al-Dihlawi (2005) agreed with other scholars, such as Ibn Khaldun (d. 1406) and al-Maqrizi (d. 1442), that overall human well-being to be the end-product of interaction over a long period of time between a number of economic as well as moral, intellectual, social, demographic and political factors in such an integrated manner that none of them is able to make an optimum contribution without support fromo the other. Justice occupied a pivotal place in this whole framework. There was an acute realization but society cannot develop effectively without justice, but instead will decline and disintegrate. This focus on justice was undoubtedly the outcome of its pivotal role in the Islamic worldview (Chapra, 2000). Al-Dihlawi (2005) introduced the theory of human civilisational development (irtifaqat) which inscribes four socio-economic developmental stages, while comparing it with growth of mankind i.e. infancy, childhood, adultness and geriatric. This unique theory of al-Dihlawi is treated as data tools (Muhammad, et al., 2011). It shows that al-Dihlawi articulated a naturalistic understanding of the genesis of social life and the evolution of civilization, outlines the factors involved in the decline of the state and the empire, and sets forth a program for dealing with a broad range of emergencies (Syros, 2012).

Al-Dihlawi's dominance of thought in this book was heading towards the innovation of mind to explain what should be carried out as Muslims to practice Islamic law. Consequently, Pirbhai (2009) noted that al-Dihlawi most directly laid out his views on the ideal socio-political structure for Muslim in particular and humanity in general. He wrote that irtifaqat are universal and their principles agreed upon despite variations in the pattern and ramifications of irtifaqat.

\section{Al-Dihlawi's Prototype Debate for Stimulating Arguments Insertion: Revisited}

Al-Dihlawi developed two important theoretical initiatives. The first was to extend the use of ijtihad (individual rational judgement). This was related to a revolutionary and modern idea, that the sharia should be interpreted in the light of the circumstances under which it was formulated, and that it must be adapted to changing needs in the present-day world. It must respond to the human condition which may differ from time to time and from place to place. Secondly, al-Dihlawi set out to resolve the differences between the Jurists and Sufis mystical approaches to religion. He advocated 'down with all systems', and put forward an approach based on reconciliation (tatbiq) (Black, 2011).

The idea of transformation presented by al-Dihlawi considerably longer than his age. Although he died since 
several centuries ago, but his informative inspirations and critical thoughts still remain and survive in accordance with the historical levels in the future. Through the Book of Hujjat Allah al-Baligha, al-Dihlawi seen trying to create theories that dealt with Quran and Sunna as the core as consistent with Sura al-An'am (The Cattle), verse 149:

\section{Say, "With Allah is the far-reaching argument. If He had willed, He would have guided you all."}

The discussions in this book are suitable with the title as sketched by al-Dihlawi because of commentaries embodied by him decorated with brilliant arguments, attractively and impressively. All of his opinions and insights discussed and reviewed carefully. His discourse was also not provoke arguments to put fault or errors that could be considered contrary to Qur'an, Sunna and shari'ah rules. His reviews were not only logical, even appropriate to the passage of time and it was plausible to put into practice in the lives of even hundreds of years this book was written (AlDihlawi, 2005)

For example, in the issue of Hakikat al-Nubuwwah wa Khawasiha (the true nature of prophecy and its characteristics) Al-Dihlawi (2005) commented on the Prophet's mandate to remove human straying and guide them to the right path. Al-Dihlawi pointed out the confirmation of God's proof (hujja) for His servants in His sending the prophets is that most people are created in such a way that they are not able to know their rights and duties, without an intermediary. Rather, either their capacity is weak so that it becomes strenght by the messages of the prophets, or among them there are evils which cannot be prevented except by compulsion in spite of themselves, while they are to be held accountable in this world and the next. Al-Dihlawi explained that in order to mobilize the human relationship with the divine God, they did not command speculating about the essence of God, may He be Exalted, and His Attributes, for most people are not capable of doing this. Al-Dihlawi argued with sura al-Najm (The Star) verse 42:

And that to your Lord is the finality

And also with the Prophet (pbuh) words below:

"Contemplate on the signs of Allah but do not think about Allah (Himself)."1

The Prophet (pbuh) also said:

\section{There should be no speculation about the the Lord²}

From this view his arguement looks logical, due to the mind is not able to achieve that the abstract things, especially to think about the Essence of God.

Al-Dihlawi (2005) also stressed on the basis of religion is one, upon which the prophets agree and that any variations are in the divine law and the codes (manahij). The prophets concur that God is unique in being worshiped and being asked for help, and that He transcends everything inapropriate to Him. Likewise they agree on the types of pious actdrions, whether purity, prayer, the alm tax, fasting, pilgrimage, the drawing near to God through supererogatory acts of worship such as petitionary prayer, the remembrance of God (dhikr), and the recital of the scripture which was revealed from God. In like manner they agree on marriage, forbidding adultery, establishing justice among people, forbidding oppression, establishing punishment for the disobedients, and making efforts to spread the ordinance of God and his religion. This is the basis of the religion and for this reason the Noble Quran only discussed what God willed out of the 'why' and 'wherefore' of these things, for they were agreed upon by those in whose Quran was revealed. Disagreement only concerned the forms and embodiments of these matters. Thus, in the Law of Moses, the direction of prayer was Jerusalem and in the law of our Prophet, the Ka'ba. The Law of Moses prescribed stoning (for the fornicator) while our law has stoning for the married one and flogging for the unmarried one. In Moses' law there is retaliatory punishment only, while in our law there is both retaliation and blood money. Likewise are the variations they contain about the times of act worship, the proper manner of performancing them, and their essential principles. In summary, the particular situations according to which types of pious actions and the supports of civilizations are set out and founded, are the divine law and the code (Al-Dihlawi, 2005).

\footnotetext{
${ }_{1}^{1}$ Hadith narrated by Abu Nu'aym al-Asbihani, Hilyah al-Auliya, no hadith: 7928.

${ }^{2}$ Hadith cited by al-Suyuti in al-Dur al-Manthur, vol. 6, p. 130, in explanation of Quran, Sura al-Najm verse 42. 


\section{The Application of Jurisprudence and Mysticism Discourses as Discussion Way}

Al-Dihlawi has given in Hujjat Allah al-Baligha an exhaustive account of the science of hadith and has unravelled the secrets underlying it. The book is so informative on this point that it won't be an exaggeration to call it a work of the tradition (Jalbani, 1967). But when visiting in some corner therein, al-Dihlawi (2005) tried to combine elements of sciences through jurisprudence and mysticism as a pattern of debate. Al-Dihlawi ideas in this work were seen as partnership between the two harmonized and applied sciences to support the principles of shariah as a stability between the worldly and hereafter demands. However, Sufism elements more dominant if viewed in another angle.

Previously, al-Ghazali has adopted elements of Sufism and jurisprudence in his book Ihya' 'Ulum al-Din, and not surprisingly, al-Dihlawi tended and agreed to focus on al-Ghazali thoughts. This issue could be found from al-Dihlawi's writing style which is similar to Ihya' 'Ulum al-Din during the debate on the phenomenon of jurisprudence and Sufism. It should be noted, the debate in the book of Hujjat Allah al-Baligha emphasizes the spiritual character of the elements Islamic law and its philosophical doctrine, as well as applying Sufism perspective as fundamental of strength in combination with jurisprudence. Al-Dihlawi introduced its own framework that is a combination of mystics, traditionalists, theologian, and jurists practices. This framework well-known as Tareq Shah Wali Allah which aims to build Sufism reformation and Muslims ethics (Mohd Amin, 2010).

In this book also, al-Dihlawi (2005) reviewed the issue of jurisprudence in several chapters, including purification, manners enter into the toilet, human nature, the law on water, prayers, etc. The concept displays al-Dihlawi's pattern of thought which headed towards the values of Sufism, which explain of the mysteries of the nature practices. For example, he elaborated on covering human private parts while attempting to perform prayers by quoting a piece of hadith:

Whenever anyone of you stands for the prayer, he is speaking in private to his Lord or his Lord is between him and his Qibla. $^{3}$

Al-Dihlawi (2005) explained that during praying, a feeling of misgivings often arise and come to bother. Therefore, every Muslim must refuse this interference which caused by the whispers of Satan. He then argued with the following hadith:

The prayer one of you would be cut off by the passing of woman, donkey, and black dog. ${ }^{4}$

Al-Dihlawi (2005) described the meaning of this hadith which reveal the secrets on prayers legal requirements. Surely every prayer practices must be attended with full of sincerity towards Allah, and quite normal that interferences often occur while performing this kind of worship, such as women, mule and dog interruption. He explained that the true meaning of prayer was Muslim supplications to the Lord, and certainly, the feeling to women was mixed-up one's heart and refracted from the true meaning of prayer. While crossing the dog means the devil who aims to destroy Mulims, as well as mule has same role with dog. Hence al-Dihlawi concluded that prayer consists of three conditions; ie submission to Allah with heart, remember Him by the tongue and glorify Him with the body.

When discussing the issue of al-iqtisad fi al-'amal (the golden mean in practices), al-Dihlawi (2005) described a precise reality that is the disease can lead epidemic to a person when hit by feeling of bored, due to it will haunt submissive and obedient nature. And finally it will affect the reputation of a worshiper, as the words of the Prophet:

Indeed for everything there is a zeal, and for every zeal there is a slackening. ${ }^{5}$

Al-Dihlawi (2005) explained the implied secrets in every practice namely various benefits conferred on Muslims by their obedience and submission to Allah. However, this may not more fruitful unless they really sincere to Allah by warn and strengthen themselves with earnestly determination. Shariah puts duties and responsibilities to perform obedience according to one's ability, as a healing medicine to treat the diseases, the dosage is certainly not more and less. AlDihlawi then stated the purpose of the above hadith was an effort to generate goodwill attributes to develop themselves by not stucking to any ramifications agenda. He also pointed out that the obedience is the nature of steadfast and produce good results and indirectly would reject the hypocritical nature that does not give any benefit. He stressed on maqasid al-jalalah (the honourable goals) in Islamic law by studying religion in order to synonymous with soul and hence

\footnotetext{
${ }^{3}$ See al-Bukhārī. (1980). Sahịh al-Bukhārī, book al-Solah, chap. Idha badarahu al-buzaq, vol. 2, p. 183, hadith number 400.

4 See Muslim. (2005). al-Jāmic al-Șahịḥ, chap. Qadri ma yasturu al-musalli, vol. 3, p. 83, Hadith number 790.

${ }_{5}^{5}$ See al-Tirmidhi (1975), Sunan al-Tirmidhi, vol. 4, hadith number 2453, p. 635. 
obedience to Allah would become fresh. Therefore, every practice whises to be carried out continuously as the words of the Prophet:

\section{The most beloved good deeds to Allah are those that are done regularly, even if they are small. ${ }^{6}$}

Hence, al-Dihlawi developed a theory of the relationship between revelation and its socio-historical context by arguing that the ideal form of religion is synonymous with the ideal form of nature. The actualized manifestations of the ideal religion descend in successive revelations depending upon changing material and historical conditions. Every succeeding revelation reshapes the world into a new gestalt which embodies religion. Religion, though in essence unchanging and universal, adapts in form to fit within the contemporary customs, faiths and practices of the receiving community. Al-Dihlawi uses the analogy of God as the physician who prescribes medication according to the needs, temperament, age, and so on, of the patient (Jackson, 2011).

\section{Ideas of Discussion: In Generating Moderate Values}

The book Hujat Allah al-Baligha was al-Dihlawi's highly valuable and worth thoughts in the intellectual discourses market. He explained the chapters which is associated with the panoramic shariah wisely, meticulously, and cautiously. Similarly, he described the issues that touched on current issues in relating to the social, economic, political etc., thoughtfully and comprehensible. His reviews and comments are parallel with the rule of law that reflect his credibility as a real intellectual. His work seems to convey a message of moderation for all levels of human exposure on religious affairs.

From here this book was impacted to intellectuals scientifically at various levels about al-Dihlawi's ideas of reform in the perspective of religion. Al-Dihlawi explained his ideas in simple, but the commentary was universal and comprehensively. He did not invent the elusive terms or severe sentences, but by excellent layouts and interesting words that show his Arabic mastery. When debating the issue of jurisprudence, he did not show himself as a Hanafi follower and did not restrain the readers to be bound by one opinion and bullying others view, indeed he focused on the issue of religion itself by describing the secrets of Islamic law.

Through this book, he did not like to raise any gimmicks and bounced polemics in religious teachings, due to its extremely detrimental to the religion values itself and could lead to the disintegration of community. He never used his position as religious experts to seek worldly influence, even he was not interested directly to pretense in religious matters. Thus, the purposes of his work were to explain the issues pending in addition to preaching the messages to the public.

The descriptions in this book also shows his intellectual work, in which all the reviews were not specified excessively. Al-Dihlawi did not stagnant and dragging the reader to accept blindly his expressed opinions, nor to submit and conform to his views, neither to straiteneth the debate area in one direction, without looking to other way. This book opens a particular subject thoroughly and does not leave any spaces of doubt. For example, the review of jurisprudence and Sufism elements did not show religious contradictions and provoke skepticism debatable. He brought clean idea of Sufism and fully comply by the Qur'an and sunna of the Prophet aspirations. Although he was a spiritual master (shaykh) in the Naqshbandi Sufi order (Rozehnal, 2004), but this book does not serve as a tool to develop his order teachings.

In contrast to wahdat al-wujud (unity of existence) by Ibn Arabi (d. 1240), and the concept of wahdat al-suhud (unity of contemplation) carried by Sirhindi (d. 1624) which are confusing the Muslims at that time. These two concepts are not agreed by most scholars as it could mislead their faith. (Baldick, 1992). Amid the turmoil of the Muslims, alDihlawi (2005) performed to shed light on the true concept of faith which is rooted in the Quran and Sunna. With this statement, the theory of creed thought should not be based on reason alone, but must be absorbed by the two trustworthy sources.

\section{The Exploitation of Orientalist against Al-Dihlawi Statement}

Naturally the Orientalists felt a twinge of envy for the purity of Islam and the Muslims, especially to the Islamic scholars who uphold the Quran and Sunna as the basis for appreciation of life. They did not pleased to see the teachings of Islam practiced by Muslims comprehensively and tried hard to find a way to destroy Islam and its teachings (Zaqzuq, 1989).

An orientalist named Gibb (d. 1971) has bias hypothesized towards the teachings of Islam brought by Prophet Muhammad. His statement was included in his book Bunya al-Fikr al-Dini by discussng Islam wrongfully and

6 See al-Bukhārī. (1980). Șahịḥ al-Bukhārī, book al-Solah, chap. Al-qasdu wa al-mudawama min al-'amal, vol. 8, p. 98, hadith number 6464. 
unreasonable (Badawi, 1993). According to Gibb (1959), Islamic thought developed on a variety of supernatural belief and creed professed by the Arabs. He explained that the Prophet Muhammad had studied all these aspects and make some modifications and then gave a new brand of religion called Islam. The new religion according to Gibb considered in accordance with the Arab culture at the time. He strengthened his opinion by exploiting an excerpt from the book of Hujjat Allah al-Baligha. He quoted the words of al-Dihlawi in this book by making irresponsible comments and impunity interpretations. The conclusions specified extremely away and in contrast to the purposes to be served by al-Dihlawi. AlDihlawi's writing quoted by Gibb (1948), which was then interpreted as misguided as follows:

\begin{abstract}
"Indeed, the rise of Muhammad as the Messenger is to carry out the mission which includes other missions. The most important part of the mission of Muhammad was his mission to the people of Prophet Ishmael. Such a mission would make Muhammad shariah content should be consistent with various traditions and rituals that they already have, because it is actually the shari'ah of Muhammad just reforms of what already exists in those Arab nations and not to burden them with a new doctrine completely they never knew".
\end{abstract}

As for the complete text of Hujjat Allah al-Baligha that should be parsed by Gibb is as follows:

\begin{abstract}
"Thus you should know that the Prophet was sent with the hanifi religion of Ishmael (nonotheism) to straighten their crookedness and bring their distortion to an end, and to spread their light, and this is His saying [the religion of your father Abraham (see Quran 22:78]. Since this was the state of affairs it was necessary that the principles of that religion were accepted and its practice affirmed; for since the Prophet had ben sent to a people in which a remnant of the rightly-guided practice still remained, there wasn't any sense in changing this and altering it. Rather it was necessary to affirm it since it would be easier for them, and proven over against their objection. The children of Ishmael had inherited the codes of their father Ishmael, and remained following that divine law until the time of 'Amr ibn Luhay, for he interpolated things into it according to his worthless opinion and thus was the worshipping of idols, allowing a bull to wander at will, and setting free a she-camel, so religion was thereby falsified, and the sound was mixed with the corrupt and ignorance, polytheism and unbelief overcame them. Therefore, God sent our master Muhammad to straighten their deviations and to reform their corruptions...."
\end{abstract}

From this perspective, Gibb's statement was an initial step to enforce his erroneous thinking that is applied with alDihlawi's idea. His view seems in line with al-Dihlawi. Meanwhile, his comment on quotations in the book of Hujjat Allah al-Baligha was to complete his evil accusations against the Prophet and Islamic teachings that supposedly taken from earlier religious traditions and rituals. So, indirectly, this Gibb's statement gave a negative impression of al-Dihlawi's integrity as an Islamic famous intellectual figure.

\title{
7. Conclusion
}

Al-Dihlawi was an eminent religious scholar and an Islamic philosopher. He was a prolific writer whose contribution extended over the entire spectrum of classical Islamic disciplines. He possessed in his writings a mixture of various thoughts. He wrote a number of books on different subjects, which testify his scholarship and deep thinking. His work Hujjat Allah al- Baligha which is magnum opus, fully reflects his holistic vision of life. In his view point, life with all its facets is a manifestation of divine unity.

Al-Dihlawi as a member of old scholarly family of Delhi attempted to redress the balance of power in favour of Islam in India. He considered the struggle of Muslim community particularly about the crisis of confidence that has eroded due to the element of superstitious beliefs and practices of Hinduism at that time. He tried to construct this book as an explanation of the confusion that occurred in religious issues, as well as a guide for Muslims to return to the path of Allah and the Sunnah of the Prophet. The book of Hujjat Allah al-Baligah presented arguments which is processed with attractive words and the fundamental debate was hovering in the scope of religion. The processing of this book is full ingredient that become a reference to fulfill the values of Muslim faith.

The writing pattern deemed very structured by loading different topics within each chapter. While in term of content analysis of this book indicated al-Dihlawi's scholarship himself on the current realities that are implemented by the arguments from Qur'an and Sunna. Moreover, the all facts which inspired by al-Dihlawi hundreds of years ago still relevant and could adopted in the scholarly marketplace until today. The style which displayed was really exciting, beautiful and easy to understand. It described the implicit and explicit meanings and clarified its position in accordance with the symbols of the term presented.

In addition, the uniqueness of this book reflected its process which adopting highly intellectual approach to shape the genius thought. Through various methods and observations, al-Dihlawi managed to explain the religious elements as 
guidance through organized and coordinated submission to create benefits to the community. Its arguments featured the meaningful and symbolic layers of word. Hence it seems to be formed from the beginning, through references that had been provided. This book successfully explained different legal issues and traditions of the Prophet by inserting more refined elements in the arena of debate. It also gives special attention to the social aspects by presenting various theories of economic, political, social and human development of civilization from time to time.

\section{References}

Badawi, A. (1993). Mawsu'ah al-Mustashriqin [Encyclopedia of Orientalists]. Beirut: Dar al-IIm Lilmalayin.

Baldick, J. (1992). Mystical Islam: An introduction to Sufism. London: I.B. Tauris \& Co Ltd.

Black, A. (2011). The History of Islamic Political Thought: From the Prophet to the Present. UK: Oxford University Press.

Al-Bukhārī, M. I. (1980). Șaḥị̄ al-Bukhārī. Vols. 2 \& 8. Riyadh: al-Salafiah.

Chapra, M. U. (2000). The Future of Economics: An Islamic Perspective. United Kingdom: The Islamic Foundation.

Al-Dihlawi, S. W. A. (2005). Hujjat Allah al-Balighah [The Conclusive Argument from God]. Damscus: Dar al-Jail.

Gibb, H. A. (1948). The Structure of Religious Thought in Islam. The Muslim World, 38(1), 17-28.

Hermansen, M. K. (1996). The Conclusive Argument from God. New York: Brill.

Jackson, R. (2011). Mawlana Mawdudi and Political Islam: Authority and the Islamic State. New York: Routledge.

Jalbani, G. N. (1967). Teachings of Shah Waliyullah of Delhi. Pakistan: SH. Muhammad Ashraf Press.

Kaplan, L. V. (2010). Theology and the Soul of the Liberal State. New York: Rowman \& Littlefield.

Mohd Amin, W. M. A. (2010). Tasawwuf Al-Dahlawi Menghadapi Kebejatan Akal Dan Akhlak Zamannya [Sufism of Al-Dahlawi: Facing on intellect and moral impairments in his time]. Workpaper presented in Gagasan Islah dan Tajdid Shah Waliyullah al-Dihlawi Seminar. Held by Institut Kefahaman Islam Malaysia (IKIM).

Muhammad, H., et al. (2011). Social Thoughts of Shah Wali Ullah in Modern Prospective. Interdisciplinary Journal of Contemporary Research in Business, 3(8), 331.

Muslim, A. H. (2005). Al-Jāmił al-Ṣahị̣̂. Vol. 3. Beirut: Dār al-Jīl.

Pirbhai, M. R. (2009). Reconsidering Islam in a South Asian Context. New York: Brill.

Rahman, F. (2003). Revival and Reform in Islam: A Study of Islamic Fundamentalism. Oxford: OneWorld.

Rozehnal, R. (2004). Debating Orthodoxy, Contesting Tradition. Islam in World Cutlures: Comparative Perspectives. Santa Barbara, 103-131.

Siddiqi, A. H. (1966). Renaissance in Indo-Pakistan: Shah Wali Allah Dihlawi. In Sharif, M. M. (Ed). A History of Muslim Philosophy, vol. 2. Wiesbaden: Otto Harrassowitz.

Syros, V. (2012). An Early Modern South Asian Thinker on the Rise and Decline of Empires: Shāh Walī Allāh of Delhi, the Mughals, and the Byzantines. Journal of World History, 23(4), 793-840.

Al-Tirmidhi, M. I. (1975). Sunan al-Tirmidhi. Vol. 4. Egypt: Mustafa al-Babi al-Halabi.

Zaqzuq, M. H. (1989). Orientalisme Kesan Pemikirannya terhadap Tamadun Islam [The Orientalism: Its Thoghts Effect on Islamic Civilization]. Kuala Lumpur: Dewan Bahasa dan Pustaka. 